\title{
Effect of graphene oxide nanoparticle coatings on the strength of packaging paper and its barrier and antibacterial properties
}

\author{
Maliheh AKHTARI $^{1}$ \\ Mohammadreza DehghaNI-FIROUZABADI² \\ Meysam AliABADI ${ }^{2}$ \\ Mehdi ARefKhan ${ }^{3}$ \\ ${ }^{1}$ Islamic Azad University \\ Bojnourd Branch \\ Department of Wood and Paper Science \\ \& Technology \\ Bojnourd \\ Iran \\ ${ }^{2}$ University of Agricultural Sciences \\ and Natural Resources \\ Department of Wood and Paper \\ Engineering \\ Gorgan \\ Iran

\section{${ }^{3}$ Tehran University} \\ Department of Wood and Paper Science \\ \& Technology \\ Tehran \\ Iran
}

\section{Auteur correspondant /}

Corresponding author:

Maliheh Akhtari -

maliheh.akhtari@gmail.com

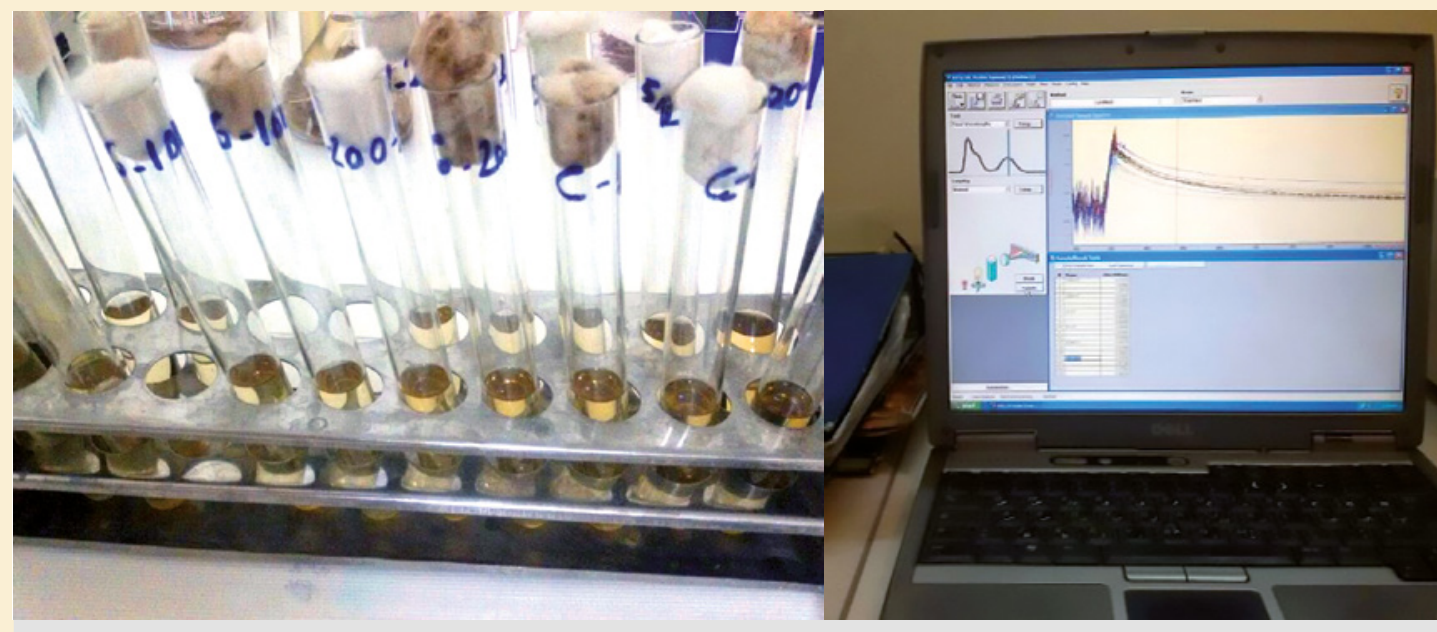

Photo 1.

Paper analysis.

Photos M. Akhtari.

Doi : $10.19182 / \mathrm{bft} 2019.342$. a31796 - Droit d'auteur @ 2019 , Bois et Forêts des Tropiques @ Cirad - Date de soumission : 15 avril 2019 ; date d'acceptation : 27 mai 2019 ; date de publication : 30 octobre 2019.

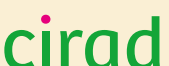

Citer l'article / To cite the article

Akhtari M., Dehghani-Firouzabadi M., Aliabadi M., Arefkhani M., 2019. Effect of graphene oxide nanoparticle coatings on the strength of packaging paper and its barrier and antibacterial properties. Bois et Forêts des Tropiques, 342: 69-78. Doi : https://doi.org/10.19182/bft2019.342.a31796 


\section{RÉSUMÉ}

\section{Effet des couches de nanoparticules d'oxyde de graphène dans la résistance du papier d'emballage, ses propriétés de barrière et son activité antibactérienne}

L'objectif de cette étude était d'évaluer la performance des nanoparticules d'oxyde de graphène dans des formulations de papier d'emballage pour améliorer les propriétés antibactériennes, physiques et mécaniques du carton. Le papier était recouvert avec des nanoparticules d'oxyde de graphène de concentrations de 100 et 200 ppm enduites avec $5 \%$ d'amidon cationique (poids $\mathrm{sec}$ ) comme aide à la rétention et pour un positionnement plus homogène des particules d'oxyde de nanographène sur la surface du papier. Les surfaces du papier enduites de particules d'oxyde de nanographène ont été caractérisées à l'aide des méthodes ATR-FTIR et SEM. Le test antibactérien a été réalisé selon la méthode de la turbidité. Pour les tests antibactériens des feuilles de papier, Escherichia coli et Staphylococcus aureus ont été utilisées comme bactéries à Gram-négatif et à Gram-positif, respectivement. Les résultats ont montré que l'absorption d'UV a été réduite et que la réduction la plus grande a été obtenue en utilisant des particules d'oxyde de nanographène de 200 ppm. La turbidité dans les échantillons qui incluent $S$. aureus était aussi plus basse. Le taux de croissance des bactéries $S$. aureus dans le contrôle et dans les échantillons de papier enduits d'oxyde de nanographène 200 ppm était de $89 \%$ et de $24 \%$, respectivement. La densité et l'épaisseur des feuilles de papier ont augmenté dans le papier enduit d'amidon cationique et de nanoparticules, en comparaison avec le papier non enduit. Les nanoparticules n'ont pas d'effet significatif dans l'épaisseur des papiers enduits. L'ajout de particules d'oxyde de nanographène a amélioré la résistance à l'air et les propriétés de barrière des feuilles de papier. Les index de résistance à l'éclatement et la déchirure ont augmenté dans le papier enduit d'amidon et de particules d'oxyde de nanographène.

Mots-clés : oxyde de nanographène, activité antibactérienne, propriétés physiques et mécaniques.

\section{ABSTRACT}

\section{Effect of graphene oxide nanoparticle coatings on the strength of packaging paper and its barrier and antibacterial properties}

The aim of this study was to assess the performance of graphene oxide nanoparticles in paper coating formulations in order to improve the antibacterial, physical and mechanical properties of paperboard. The paper was coated with graphene oxide nanoparticles at concentrations of 100 and $200 \mathrm{ppm}$ together with $5 \%$ cationic starch (dry weight) as a retention aid and for better coverage and more homogeneous positioning of nanographene oxide particles on the surface of the paper. The paper surface coated with nanographene oxide particles and starch was characterised using ATR-FTIR and SEM. The antibacterial assay was performed according to the Turbidity Method. For the antibacterial tests of paper sheets, Escherichia coli and Staphylococcus aureus were used as Gram-negative and Gram-positive bacteria respectively. The results showed that UV adsorption was reduced, with the largest reduction obtained when using nanographene oxide particles at $200 \mathrm{ppm}$. Turbidity in the samples including $S$. aureus was also lower. The growth rates of $S$. aureus bacterium in the control and the paper specimens coated with $200 \mathrm{ppm}$ nanographene oxide were $89 \%$ and $24 \%$, respectively. The density and thickness of the paper sheets increased in the paper coated with cationic starch and nanoparticles in comparison with uncoated paper. The nanoparticles had no significant effect on the thickness of coated papers. The addition of nanographene oxide particles improved the resistance to air and barrier properties of paper sheets. The burst and tear indexes increased for the paper coated with starch and nanographene oxide particles.

Keywords: nanographene oxide, antibacterial activity, physical and mechanical properties.

\section{RESUMEN}

\section{Efecto de los recubrimientos de nanopartículas de óxido de grafeno en la resistencia, las propiedades de barrera y la actividad antibacteriana del papel de envolver}

El objetivo de este estudio fue evaluar el rendimiento de las nanopartículas de óxido de grafeno en formulaciones de recubrimiento de papel para mejorar las propiedades antibacterianas, físicas y mecánicas del cartoncillo. El papel se recubrió con nanopartículas de óxido de grafeno con concentraciones de 100 y 200 ppm acompañadas de almidón catiónico al 5\% (porcentaje respecto al peso en seco) como ayuda a la retención, mejor cobertura y posicionamiento más homogéneo de las partículas de óxido de nanografeno en la superficie del papel. La superficie del papel recubierta con partículas de óxido de nanografeno y almidón se caracterizó mediante ATR-FTIR y SEM. La prueba antibacteriana se realizó según el método de la turbidez. Para las pruebas antibacterianas de las hojas de papel se utilizaron también Escherichia coli y Staphylococcus aureus como bacterias gram-negativa y gram-positiva, respectivamente. Los resultados mostraron que la absorción de UV se redujo, y que la mayor reducción se obtuvo al utilizar partículas de óxido de nanografeno a 200 ppm. También fue menor la turbidez en muestras que incluyen $S$. aureus. La tasa de crecimiento de $S$. aureus bacterium en el control y en muestras de papel recubierto con óxido de nanografeno de $200 \mathrm{ppm}$ fueron del $89 \%$ y $24 \%$, respectivamente. La densidad y el espesor de las hojas de papel aumentó en el papel recubierto con almidón catiónico y nanopartículas en comparación con el papel no recubierto. Las nanopartículas no tienen efecto significativo en el grosor de los papeles recubiertos. La adición de partículas de óxido de nanografeno mejoró la resistencia al aire y las propiedades de barrera de las hojas de papel. Los índices de resistencia a la explosión y al desgarro aumentaron en el papel recubierto con almidón y partículas de óxido de nanografeno.

Palabras clave: óxido de nanografeno, actividad antibacteriana, propiedades físicas y mecánicas. 


\section{Introduction}

Paper substrates are widely used in many industries such as packaging due to their high strength, flexibility, low cost and recyclability. However, they have a complex structure, with cellulosic units arranged at multiple levels including molecules, fibrils, fibers and fiber networks (Afra et al., 2013). Paper and its products are closely related to our lives and work. Because paper contaminated by bacteria gives rise to the spread of disease, increasing attention has been focused on the research of antibacterial paper (Deng et al., 2012).

With the growing public health awareness of disease transmissions and cross-infection caused by microorganisms, use of antimicrobial materials has increased in many application areas like protective clothing for medical and chemical works, other health related products (Duran et al., 2007), antibacterial packaging material that can improve product quality and keep it free from microbial adhesion (Park and Zhao, 2004), etc. It is of great significance to study antibacterial paper in order to prevent the spread of harmful bacteria and infection of infectious disease. The antibacterial paper is putting a small amount of antimicrobial agent to spraying, dipping, sizing, coating, the modified fiber added to ordinary paper. The antibacterial agent generally can be divided into inorganic antimicrobial agent, organic antibacterial agent and natural antimicrobial agent (Hong and Tang, 2014). The advantages of coated paper is low cost, wide source, and easy to recycle. It will not cause pollution to the environment, complying with the principles of green packaging. Coating ingredient that has a crucial influence on the application of product is the most basic technology; manufacturing coated paper has a crucial influence on product use (Pang et al., 2015). Nanotechnology is presently recognized as one of the most promising areas for packaging technological improvement in the $21^{\text {st }}$ century ( $\mathrm{Hu}$ and $\mathrm{Fu}$, 2003). Nanoparticles usually ranging in dimension from 1-100 nanometers $(\mathrm{nm})$ have properties unique from their bulk equivalent.

Moreover, nanoparticles possess increased surface area and therefore increase the area of interaction with the pathogenic bacteria. They are also more likely to enter the bacterial surfaces than micron particles due to smaller size, exerting stronger effects on bacterial targets (Tran and Webster, 2011). Improving results were also reported against exposure to some fungi and insects by addition of metal and mineral nanoparticles (Taghiyari et al., 2019; Akhtari and Nicholas, 2013). But one major problem for metal-based nanoparticles is their toxicity to healthy cells due to the generation of reactive oxygen species (Xia et al., 2008). Those materials may result in severe health problems when such coated paper products are used for food wrapping or clinical applications.

Graphene Oxide (GO) is chemically modified graphene, containing hydroxyl, carbonyl and epoxy functional groups, which is obtained by synthesis of graphite with strong oxidizing agents (Alves et al., 2014). Also it has been used as a promising material for preparing new composites (Tang et al., 2013). It is well known that GO and its composites possess antimicrobial properties and have been used as antibacterial and antifungal agents (Santos et al., 2012; De Faria et al., 2014). Nanotechnology and nanomaterials have been effective to improve properties of many materials and overcome some of their drawbacks (Majidi, 2016). In the present study, we evaluated the performance of graphene oxide nanoparticles in the paper coating formulations in order to improve the antibacterial, physical, mechanical and mechanical properties of paper.

\section{Materials and methods}

\section{Materials}

Nanographene oxide particles with thickness of 3.4-7 nm, average number of layers 6-10, surface area of $100-300 \mathrm{~m}^{2} / \mathrm{g}, \sim 99 \%$ carbon purity and bulk density of $1 \mathrm{~g} /$ cc were purchased from Nanosany Co., Ltd. Figure 1 shows a microphotograph of the layer structure nanographene oxide. Cationic starch was obtained from Merck Chemicals Co., Ltd. A4-size paper sheets with a grammage of $80 \mathrm{~g} / \mathrm{m}^{2}$ and an average thickness of $112 \mu \mathrm{m}$ with trade name Copimax was use as a controlled paperboard for the coating.

\section{Preparation of coating solutions}

In this study, the paper was coated with graphene oxide nanoparticles with concentrations of 100 and 200 ppm accompanied by cationic starch at the $5 \%$ percent (based on dry weight) as a retention aid, better coverage and more homogeneous positioning of nanographene oxide particles on the paper surface. The starch coating solution by gelatinizing $5 \%$ concentration was prepared by adding $5 \mathrm{~g}$ starch in the $100 \mathrm{~mL}$ distilled water. This mixture cooked at a temperature of $90^{\circ} \mathrm{C}$ for 30 minutes. It was kept in a constant temperature water bath at $50^{\circ} \mathrm{C}$ and used it for surface coating. Graphene oxide nanoparticles suspension 100 ppm and $200 \mathrm{ppm}$ were prepared by adding respectively $100 \mathrm{~mL}$ and $200 \mathrm{~mL}$ colloids solutions of graphene oxide nanopar-

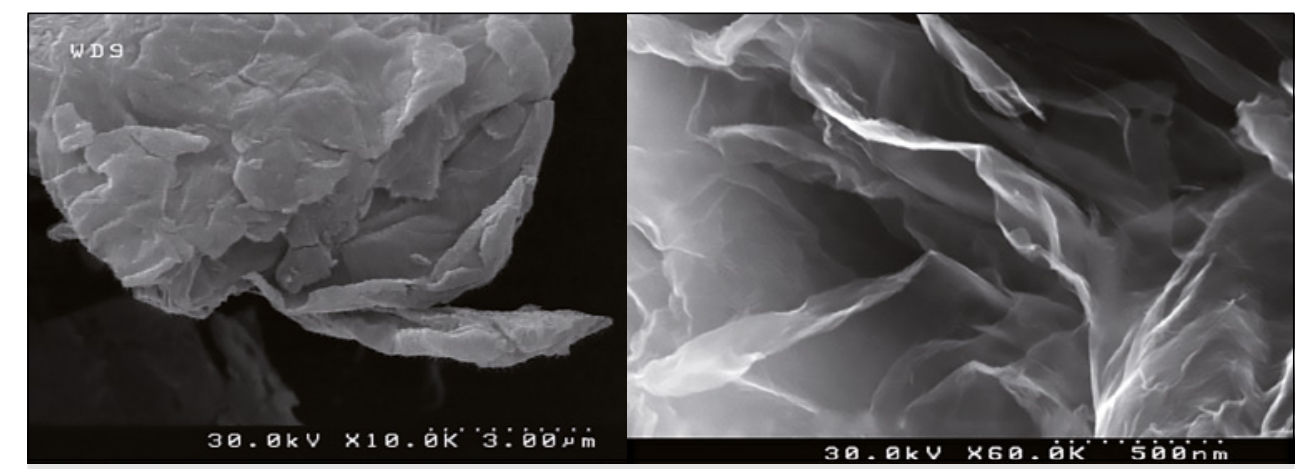

Figure 1.

SEM image of graphene oxide nanoparticles as the layer structure. 
ticles in the $900 \mathrm{~mL}$ and $800 \mathrm{~mL}$ gelatinize starch solution. The mixtures were then homogenized and stirred using a magnetic stirrer unit for $30 \mathrm{~min}$.

\section{Paper sheets coating}

Coating solutions were coated onto paper sheets using the Auto Bar Coater (GBC - A4 GIST Co., Ltd). $10 \mathrm{~mL}$ of coating solutions was poured on the paper along the width at one end and the applicator rod was immediately swept along the length of the paper sheets. The applicator speed of the coating was set at $25 \mathrm{~mm} / \mathrm{s}$. The coated paper sheets were dried at room temperature for 24 hours. Before characterization, all samples were conditioned at $27^{\circ} \mathrm{C}$ with $65 \%$ relative humidity for at least $24 \mathrm{~h}$ in accordance with ISO 187.

\section{Assessment of paper sheets for antibacterial properties}

The antibacterial assay was performed according to the Turbidity Method. Culture medium (BHIB) was placed in an autoclave $\left(15 \mathrm{~min}\right.$ at $\left.121^{\circ} \mathrm{C}\right)$. Coated and uncoated sheets were sterilized in an oven $\left(0.5 \mathrm{~g}, 2 \mathrm{~h}\right.$ and $\left.150^{\circ} \mathrm{C}\right)$ were sterilized. Sterilized papers were inserted into a tube containing sterilized culture; then $0.05 \mathrm{~mL}$ with $0.05 \%$ concentration of gram negative bacteria (Escherichia coli) and gram positive bacteria (Staphylococcus aureus) were added separately and put into a shaker incubator (160 rpm and $37^{\circ} \mathrm{C}$ ) for $24 \mathrm{~h}$. Controls were also run in parallel. The turbidity of the suspensions was measured at $600 \mathrm{~nm}$ using a spectrophotometer.

\section{Characterization of paper sheets}

The surface chemical groups of the samples were measured by Attenuated Total Reflection-Fourier Transform Infrared spectroscopy (Golden Gate Model, Specac Company, UK). The surface morphology of the samples was observed by scanning electron microscopy (Vega3-Tescan, Tescan Company, (zech). The samples for SEM observations were dried at room temperature, and sputter-coated with gold before observation. All paper properties were measured according to TAPPI standards. Base Weight, Thickness, Air permeability, Water absorbtion, Water Vapor Transmission Rate (WVTR), Burst strength and Tear resistance were measured according to T410om-02, T411om-05, T460om-02, T441-om-96, T448-om-09, T403om-02 and T4140m-04 standards, respectively. Five specimens were selected for the evaluation of each test. Statistical analysis was conducted using SPSS software program, version 25. The Duncan test was used to compare averages and analysis of variance (ANOVA) was performed on the data to conclude significant differences at the $99 \%$ level of confidence.

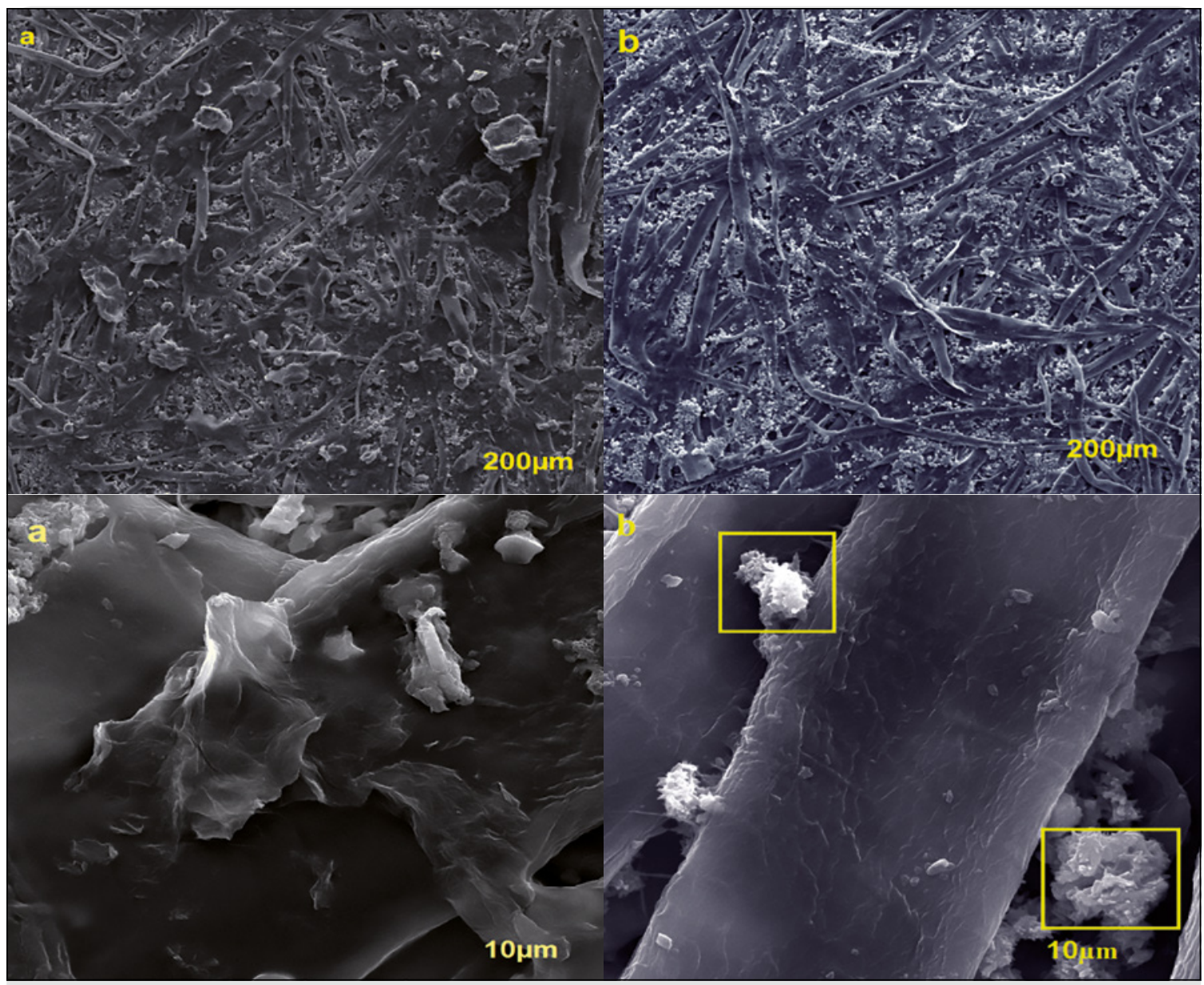

Figure 2.

SEM microphotographs of the paper surface coated with graphene oxide nanoparticles (a) and starch (b). 


\section{Results and discussion}

\section{SEM and ATR characterization}

SEM was employed to observe the surface morphological changes for paper samples after the particles deposition, and the representative SEM images of the coated paper with nanographene oxide particles and starch are provided in figure 2. On the nanographene oxide particles coated paper samples, the graphene oxide nanoparticles were distributed and covered the dense network of entwined cellulose fibers. Some of the graphene oxide nanoparticles were also observed in the fiber structure on the top surface. The lateral dimension for most of the nanographene oxide particles were around 10-50 $\mu \mathrm{m}$. SEM photos of GO shows that, the exfoliated particles were smooth with small wrinkles at the edges (Al-Thani et al., 2014). After the deposition of nanographene oxide particles and starch on the uncoated paper, microporous pores were filled with them and some gelatinous substances appeared and resulted in bridging between adjacent cellulose fibers. The average diameters of the cellulose fibers increased and more gelatinous substances were presented, hence causing more bridging and bonding between fibers, resulting in a more compact surface structure. This result is consistent with a previous study (Wu and Farnood, 2014; Li et al., 2018).

To confirm further the coating of graphene oxide nanoparticles on the paper surface, attenuated total reflection (ATR) infrared spectroscopy were recorded. The composition of paper in general is very complex. However, the major composition of paper includes cellulose, $\mathrm{CaCO}_{3}$, silicates, thickeners, and binders (Ghule et al., 2006). Figure 3 shows the ATR-FTIR spectra of the uncoated and coated paper with starch and nanographene oxide particles. The ATR-FTIR spectra of the papers showed absorption peaks of fibers, of which the main ingredient was cellulose. Starch has a similar sugar unit structure with cellulose and its structure is very close to that of cellulose (figure $3 a, b$ ).

Both of the ATR-FTIR spectra showed a peak in the range 3,400 to $3,200 \mathrm{~cm}^{-1}$ was attributed to the intermolecular hydrogen bonds. A broad band $\left(3,100-3,700 \mathrm{~cm}^{-1}\right)$ centered around $3,336 \mathrm{~cm}^{-1}$ characteristic of $\mathrm{O}-\mathrm{H}$ functional group (free and $\mathrm{H}$-bonded) is also observed. The band at $3,336 \mathrm{~cm}^{-1}$ representative of free $\mathrm{O}-\mathrm{H}$ shows decrease in intensity, suggesting that the hydroxyl functional groups are occupied with the deposition of starch and nanographene oxide particles (figure 3a, b).

The absorption peaks at $3,300 \mathrm{~cm}^{-1}$ and range from $900-1,300 \mathrm{~cm}^{-1}$, respectively, can be attributed to the $\mathrm{C}-\mathrm{H}$ stretching vibrations and $\mathrm{C}-\mathrm{O}$ of cellulose. The band at $1,640 \mathrm{~cm}^{-1}$ can be attributed to the absorbed water in the cellulose fibers (Liu et al., 2005). The relatively broad peak at $3,300 \mathrm{~cm}^{-1}$ is due to the adsorbed water content in the surface of nanographene oxide and peak at $1,600 \mathrm{~cm}^{-1}$ can be assigned to the $C-C$ vibrations from the graphitic domains (Krishnamoorthy, 2011, 2012). The FTIR spectrum of nanographene oxide in coated paper illustrates the presence of $\mathrm{C}=0$ stretching in carboxylic acidat $1,700 \mathrm{~cm}^{-1}, \mathrm{C}-\mathrm{OH}$ at $1,415 \mathrm{~cm}^{-1}, \mathrm{C}-0$ at $1,027 \mathrm{~cm}^{-1}$ and C-O-C at 1,250 $\mathrm{cm}^{-1}$ (Zhou et al., 2009).

The band at $1,735 \mathrm{~cm}^{-1}$ is characteristic of hemicelluloses. The weakening of absorption intensity of $\mathrm{O}-\mathrm{H}$ group in peaks $1,415 \mathrm{~cm}^{-1}$ and $1,407 \mathrm{~cm}^{-1}$ indicated the decrease in free $\mathrm{O}-\mathrm{H}$ group after linking with nanographene oxide particles and starch (figure 3a,b). A weak broad band at $709 \mathrm{~cm}^{-1}$ might be characteristic of $\mathrm{I}_{\alpha}$ and $\mathrm{I}_{\beta}$ phases of cellulose. The bands at $871,1,025,1,159 \mathrm{~cm}^{-1}$ are attributed to cellulose (paper composition) (Ghule et al., 2006).

\section{Physical and mechanical properties of the paper sheets}

\section{Density, coating weight and paper thickness}

Density is among the important structural properties of paper (Levlin and Söderhjelm, 1999). The apparent density of paper is also one of the physical properties of paper that impacts its strength properties. It influences almost all the mechanical, physical and electrical properties. Various hydrophilic polyelectrolytes, including cationic starch products, are used by papermakers to promote inter-fiber bonding and increase paper's dry-strength (Hubbe, 2006). The influences of nanographene oxide particles and starch on the paper's density, coating weight and thickness were also

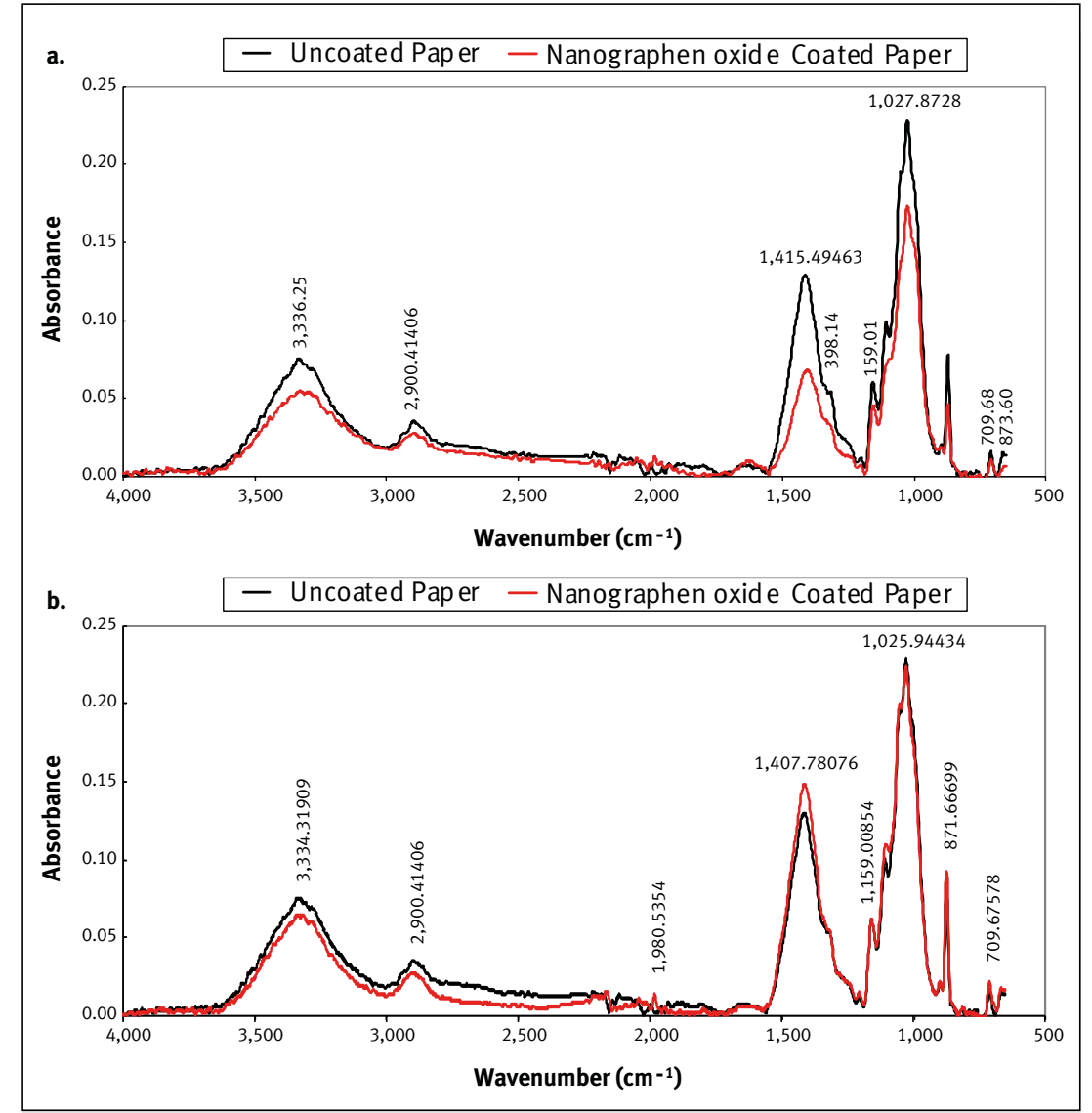

Figure 3.

ATR-FIIR spectra of the uncoated and coated paper sheets with nanographene oxide particles (a) and starch (b). 
evaluated: the results appear in figure 4. As it can be seen, density and coating weight of the paper sheets increased in the paper coated with cationic starch and nanoparticles in comparison with uncoated paper. Nanoparticles have no significant effect on the thickness of coated papers, which could be attributed to penetration of nanoparticles in the porous paper and low weight of nanoparticles. One-way analysis of variance revealed that there was no significant difference between average thicknesses of papers coated with nanographene oxide particles amounts of $100 \mathrm{ppm}$ and $200 \mathrm{ppm}$ concentrations.

\section{Water absorption, resistance to air and water vapor transmission rate (WVTR)}

It is essential for packaging material to have excellent barrier properties. For example, food packaging paper must have good oxygen and water vapor barrier properties to make sure that the food will not become bad (Wang and Jing, 2016). Figure 5 shows the barrier properties of uncoated and coated paper. Water absorption is one of the barrier properties of papers. The wetting and adsorption mechanisms of water depend on the chemical and physical heterogeneity of porous substrates, such as textiles in general and paper in specific (Werner et al., 2005). The water absorption of the coated and uncoated papers was evaluated by Cobb-test measurements
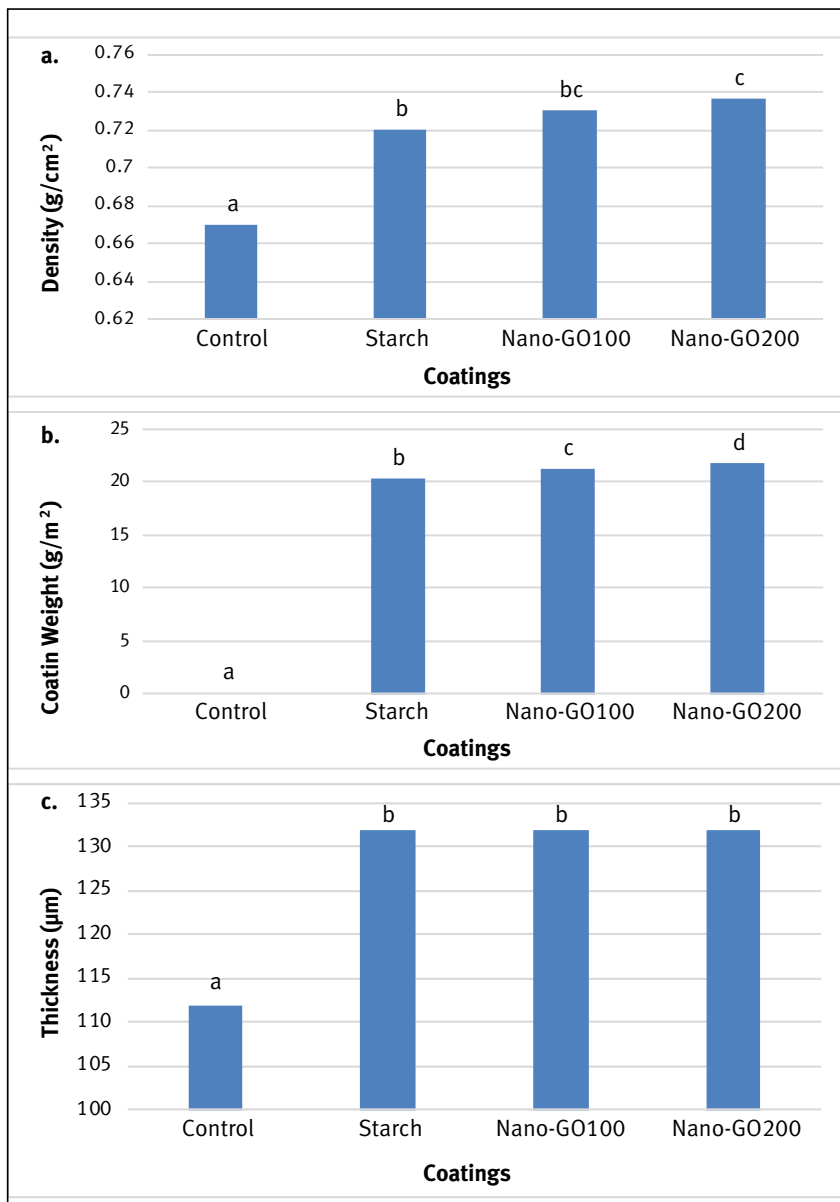

Figure 4.

The effect of coatings on density (a), weight (b) and thickness (c) of the samples.
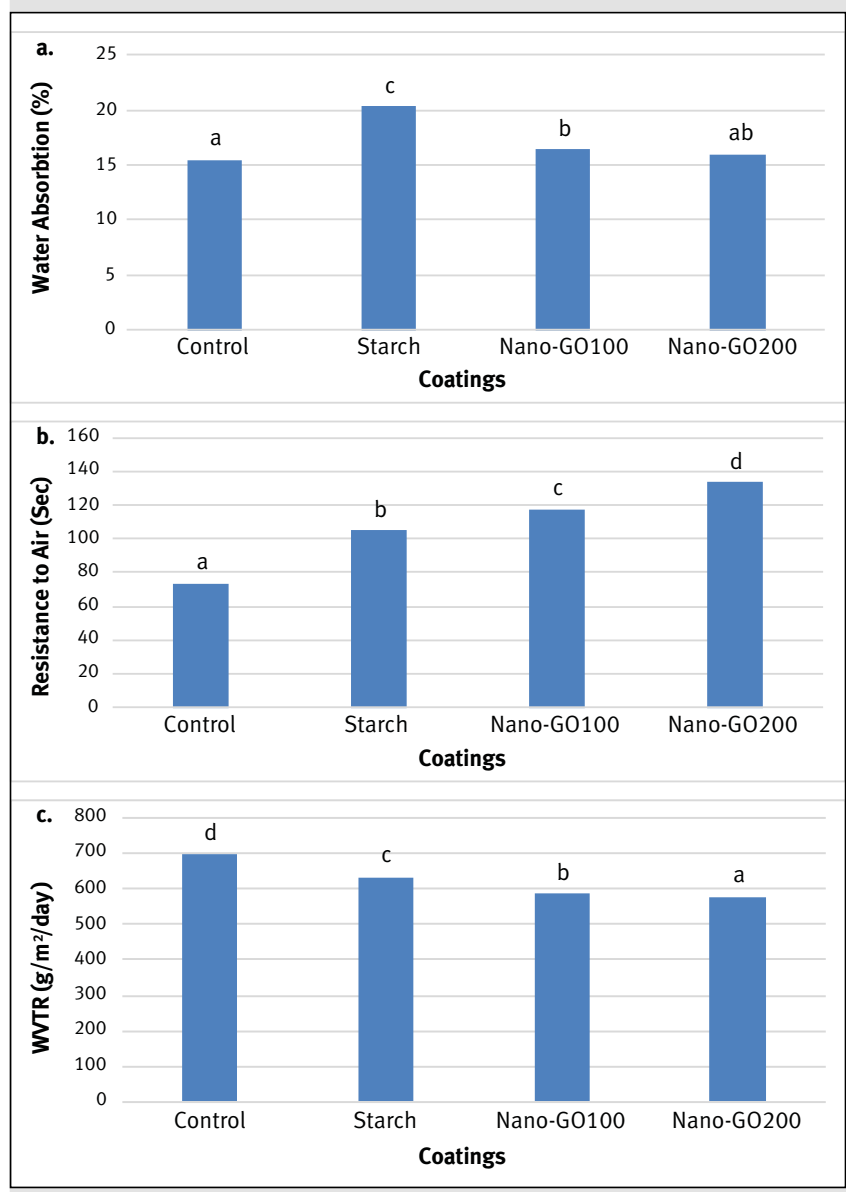

Figure 5.

The effect of coatings on water absorbtion (a), resistance to air (b) and water vapor transmission rate (WVTR) (c) of the samples.

and displayed in figure 5a. According to the results, coated paper with nanographene oxide particles have significantly decreased. These results could be attributed to the small size of the nanoparticles and higher specific surface area. These particles are more easily placed in the pores between the fibers and reduced the amount of water absorption by filling the pores. These results were confirmed by Tunc et al. (2007) and Pornasir et al. (2016). Increasing the level of nanoparticles application reduced the absorption of sample water. This decrease has a significant effect on the water absorption properties of the samples. The increase in water absorption of coated papers with starch results from higher hydrophobicity of the paper surface. Retulainen and Nurminen (1993) showed that higher-yield fibers, having a higher density of negative charge, were able to absorb cationic starch more efficiently compared to low-yield fibers. Cationic starch is a hydrophilic polymer (Kalambur and Rizvi, 2006) with high molecular mass and cationic property, that they can induce hydrogen bond with the surface of the cellulose fibers with a negative charge (Hubbe, 2006).

Due to the hydrophilic nature of fiber surfaces, it is to be expected that hydrogen bonds, in addition to London-van der Waals (dispersion) attractions, will hold the fibers together after paper is dried (Pierce, 1930; Campbell, 1947; Davison, 1980; Fowkes, 1983). 
Another important property of paper sheets is resistance to air. The objective in measurement of resistance to air of the samples was to highlight the fact that the network permeability could be better controlled in paper than in a woven fabric (Imani et al., 2011). Figure 5b shows that coatings increase the resistance to air to a great extent. The highest and lowest the resistance to air values were found in coated with nanographene oxide 200 ppm (133.66 Sec) and control (73.66 Sec) paper sheet, respectively. Duncan's multi-range test puts four measurable treatments in four different groups. Addition of nanographene oxide particles improved the resistance to air and barrier properties of paper sheets. The interaction of the nanoparticle coatings with the cellulosic paper web results in improvement of the mechanical paper strength and is attributed to hydrogen-bonding between the nanoparticles and the cellulosic fibers (Samyn et al., 2010).

The coating weight had a great effect on the WVTR of a coated paper. This can be seen from figure $5 c$, which shows that the coated paper with 200 ppm nanographene oxide particles had a low WVTR when the coating weight was high. When the coating weight was $21.70 \mathrm{~g} / \mathrm{m}^{2}$, WVTR was reduced by $577.11 \mathrm{~g} / \mathrm{m}^{2}$ day. This was because, under the equal conditions, the coated paper with higher coating weight formed a thicker layer on the surface of the paper, and these coatings were helpful to hinder water vapor from seeping through the paper. The starch and nanographene oxide particles on the paper's surface had blocked the pores on the surface from fiber and pores formed by fiber crossing; thus it had an effect on barrier function. The two factors of bond strength and bonded bonding between the fibers can be significantly increased by dry resistance additives, such as cationic starch (Mauyer, 1998). One-way variance analysis showed that there is a significant difference between measured average values at the $1 \%$ confidence level. Duncan's multi-range test puts four measurable treatments in four different groups.

\section{Indexes of burst and tear}

The mechanical properties of paper, and the strength of the fiber network, have been thought to arise from interfiber bonding - the strength of individual bonds and all the bonds within the network and from the (axial) strength of individual papermaking fibers (Robinson, 1980; Stratton, 1991). Tear index depends on fiber length, individual fiber strength, and Relative Bonding Area (RBA). In the case of a sheet having low RBA, tear strength is more dependent on fiber-fiber bondings, whereas by increasing of bonding, individual fiber strength becomes crucial in tear index (Testova, 2006). The influences of nanographene oxide particles and starch on indexes of burst and tear of the paper sheets were also evaluated, and the results are illustrated in figure 6.

Bursting strength tells how much pressure paper can tolerate before rupture. It is important for bag paper. Generally, bursting strength can depend on the fiber type, proportion and amount of fibers present in the sheet. For instance, an increase in basis weight and degree of refining will result high burst strength. Fiber length and fiber coarseness have also some effect on bursting strength. Fiber length increases burst strength and coarseness decreases it (Farouk et al., 1999). As can be seen in figure 6a, burst index increased in coated paper with starch and nanographene oxide particles. The burst index values in coated paper with nanographene oxide $200 \mathrm{ppm}$ and control were $184.63 \mathrm{~Pa} / \mathrm{m}^{2} / \mathrm{g}$ and $159.7 \mathrm{~Pa} / \mathrm{m}^{2} / \mathrm{g}$, respectively. Duncan's multi-range test puts coated papers in the same groups. The effect of coatings on the tear indexes is similar, but more slowly (figure 6b). This increase does not have a significant effect on the tear index of the samples. These results confirmed Janković-Častvan et al.'s report (2014), which indicated that values of the bursting and mechanical strengths of the paper coated by starch with sepiolite nanoparticles were increased.

\section{Antibacterial activity of the paper sheets}

The other important property of the paper coated with starch and nanographene oxide particles was the antibacterial activity. Here in, the Gram-negative bacteria (Escherichia coli) and Gram-positive bacteria (Staphylococcus aureus) were chosen as the test microorganism, and the antibacterial activity of the coated paper was measured using the Turbidity Method. The rate of growth of a bacterial culture is expressed as generation time, under standard nutritional conditions (culture medium, temperature, $\mathrm{pH}$, etc.). Generation times for bacteria vary from about $12 \mathrm{~min}$ to 24 hours or more (Lindqvist, 2006). According to figure 7, for both types of bacteria $S$. aureus and $E$. coli, by increasing the amount of nanographene oxide particles, the UV adsorption was reduced and the greatest reduction was obtained when using nanographene oxide particles $200 \mathrm{ppm}$. This

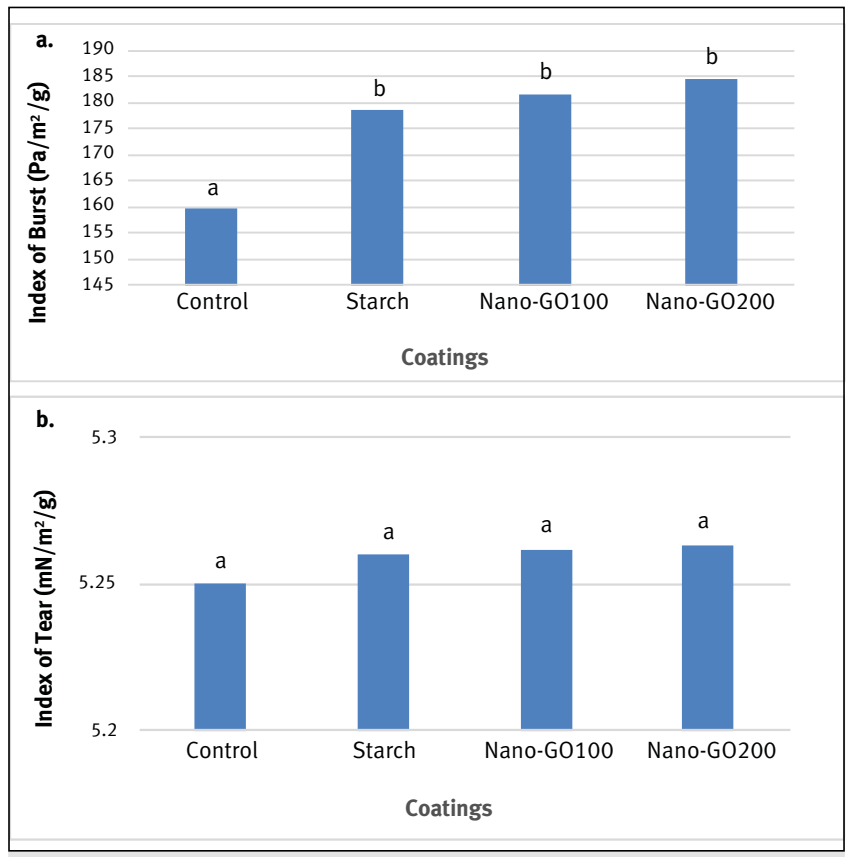

Figure 6.

The effect of coatings on indexes of burst (a) and tear (b) of the samples. 
shows that higher adsorption of nanoparticles led to higher anti-microbial effects in hand sheets. The results indicate that the growth rates of $S$. aureus (figure $7 \mathrm{a}$ ) and $\mathrm{E}$. coli (figure $7 \mathrm{~b}$ ) bacteria in the control samples were $89 \%$ and $73 \%$ respectively. With paper coated with nanographene particles $200 \mathrm{ppm}$, they reached only $24 \%$ and $34 \%$, respectively. Coating with starch also had no inhibitory effect and no significant effect on bacterial growth on paper sheets; this result was confirmed by Pornasir et al. (2016). Also, turbidity in samples including $S$. aureus was lower. As a rule, Gram-positive bacteria are more sensitive to nanometal particles than Gram-negative bacteria due to a difference in the cell walls (Yazdani et al., 2014). In Gram-positive bacteria, the cell wall is rich in mucopeptide component, while in Gram-negative ones the cell wall just contains a thin layer of mucopeptide and is primarily composed of lipoproteins and lipoprotein polysaccharides. Therefore, $E$. coli show more resistance to antibacterial materials (Tassou and Nychas, 1995). The present findings confirmed the other results reported by Sondi and Salopek-Sondi (2004) and Giang and Manolaches (2004). Therefore, nanographene oxide particles have a large specific surface area that enabled it to adsorb and fix bacteria effectively. It is clear in figure 7 that coated paper with nanographene particles showed higher resistance to bacteria than the control samples. Considering the efforts taken on the antibacterial activity of graphene oxide nanoparticles until now, Hu et al. (2010) reported the antibacterial activity of the graphene and graphene oxide towards $E$. coli. While showing minimal cytotoxicity, nanoparticles possess increased surface areas and therefore have increased interactions with biological targets (such as bacteria) compared with conventional, microparticles. Furthermore, the antibacterial effect of surface coating paper was better than that of internal additive paper, possibly because the antibacterial agent was lost in the internal additive method and was completely retained during surface coating. This is consistent with the results on physical properties (Ling et al., 2013).
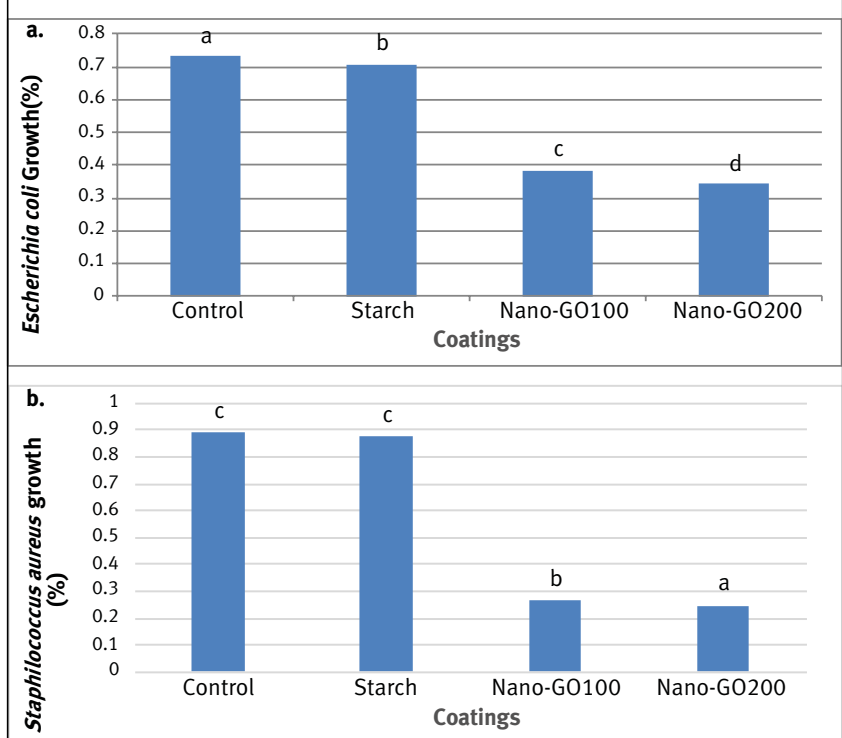

Figure 7.

Antibacterial activities of samples against Staphylococcus aureus (a) and Escherichia coli (b).

\section{Conclusion}

Antibacterial materials are widely used in daily life and effectively protect the public health. Nanographene oxide nanoparticles have been reported to demonstrate high biological activity and low toxicity. In this review, the antibacterial activity of nanographene oxide particles as a paper coating against of Escherichia coli and Staphylococcus aureus was studied by the bacterial turbidity method. Results revealed that nanographene oxide particles coatings significantly inhibited the growth of $E$. coli and $S$. aureus on the surface of papers and the antibacterial activity increased with increasing concentration. Thus, it suggests that nanographene oxide coatings could be used as an effective way.

\section{References}

Afra E., Yousefi H., Hadilam M. M., Nishino T., 2013. Comparative effect of mechanical beating and nanofibrillation of cellulose on paper properties made from bagasse and softwood pulps. Carbohydrate Polymers, 97 (2): 725-730. https://doi.org/10.1016/j.carbpol.2013.05.032

Akhtari M., Nicholas D., 2013. Evaluation of particulate zinc and copper as wood preservatives for termite control. European Journal of Wood and Wood Products, 71 (3): 395 396. https://doi.org/10.1007/s00107-013-0690-7

Al-Thani R. F., Patan N., Al-Maadeed M., 2014. Graphene oxide as antimicrobial against two gram-positive and two-negative bacteria in addition to one fungus. Journal of Biological Sciences, 14 (3): 230-239. https://doi. org/10.3844/ojbsci.2014.230.239

Alves O. L., Ana D., Moraes C. M., Simoes M. B., Fonseca L. C., Nascimento R. O., 2014. Nanomaterials. In: Duran N., Guterres S. S., Alves O. L. (eds). Nanomedicine and Nanotoxicology. Springer, USA, 1-29. https://doi. org/10.1007/978-1-4614-8993-1 1

Campbell W. B., 1947. Academic aspects of paper stock preparation. Technical Association of the Pulp and Paper Industry Journal (TAPPI), 30 (6): 177-180.

Davison R. W., 1980. Theory of dry strength development. In: Reynolds W. F. (ed.). Dry Strength Additives. TAPPI Press, USA, 1-31.

De Faria A. F., Moraes A. M., Alves O. L., 2014. Toxicity of nanomaterials to microorganisms: Mechanisms, methods, and new perspectives. In: Duran N., Guterres S. S., Alves O. L. (eds). Nanomedicine and Nanotoxicology. Springer, USA, 363-405. https://doi.org/10.1007/978-1-4614-8993-1 17

Deng J., Li W., Tang J., Wu R., Zhou X., 2012. Antibacterial Activity of Nano Silver and Its Application in Antibacterial Paper. Applied Mechanics and Materials, 200: 393-396. https://doi.org/10.4028/www.scientific.net/amm.200.393

Duran N., Marcato P. D., De Souza G. H., Alves O. L., Esposito E., 2007. Antibacterial effect of silver nanoparticles 
produced by fungal process on textile fabrics and their effluent treatment. Journal of Biomedical Nanotechnology, 3 (2): 203-208. https://doi.org/10.1166/ibn.2007.022

Farouk E., Hosseiny L., Dwight A., 1999. Effect of fiber length and coarseness on the burst strength of paper. Technical Association of the Pulp and Paper Industry Journal, 83 (5): 202-203.

Fowkes F. M., 1983. Acid-base interactions in polymer adhesion. In: Mittal K. L. (ed.). Physicochemical Aspects of Polymer Surfaces. Penum, USA, 583-603.

Ghule K., Ghule A. V., Chen B. J., Ling Y. C., 2006. Preparation and characterization of $\mathrm{ZnO}$ nanoparticles coated paper and its antibacterial activity study. Green Chemistry, 8 (12): 1034-1041. https://doi.org/10.1039/b605623g

Giang H. S., Manolaches S., 2004. Plasma-enhanced deposition of silver nanoparticles onto polymer metal surfaces for the generation of antimicrobial characteristics. Journal of Applied Polymer Science, 93 (3): 1411-1421. https://doi.org/10.1002/app.20561

Hong Y., Tang L. Z., 2014. Research on properties of antibacterial paper sprayed by nano-chitosan. Advanced Materials Research, 926-930: 214-217. https://doi. org/10.4028/www.scientific.net/amr.926-930.214

Hu A. W., Fu Z. H., 2003. Nanotechnology and its application in packaging and packaging machinery. Packaging Engineering, 24 (4): 22-24.

Hu W., Peng C., Luo W., Lv M., Li X., Huang Q., et al., 2010. Graphene-based antibacterial paper. ACS Nano, 4 (7): $4317-$ 4323. https://doi.org/10.1021/nn101097v

Hubbe M., 2006. Bonding between cellulosic fibers in the absence and presence of dry-strength agent - A review. Bioresources, 1 (2): 281-318.

Imani R., Talaiepour M., Dutta J., Ghobadinezhad M., Hemmasi A., Nazhad M., 2011. Production of antibacterial filter paper from wood cellulose. BioResources, 6 (1): 891900.

Janković-Častvan I., Lazarevic S., Stojanovic D., Zivkovic P., Petrovic R., Janackovic D., 2014. Improvement of the mechanical properties of paper by starch coatings modified with sepiolite nanoparticles. Starch - Starke, 67 (3-4): 373380. https://doi.org/10.1002/star.201400171

Krishnamoorthy K., Mohan R., Kim S. J., 2011. Graphene oxide as a photocatalytic material. Applied Physics Letters, 98 (24): 111-121. https://doi.org/10.1063/1.3599453

Krishnamoorthy K., Veerapandian M., Mohan R., Kim S. J., 2012. Investigation of Raman and photoluminescence studies of reduced graphene oxide sheets. Springer, Applied Physics A: Materials Science \& Processing, 106 (4): 501506. https://doi.org/10.1007/s00339-011-6720-6

Kalambur S. H., Rizvi S., 2006. An overview of starch based plastic blends from reactive extrusion. Journal of Plastic Film and Sheeting, 22 (1): 39-58. https://doi. org/10.1177/8756087906062729

Levlin J.-E., Söderhjelm L., 1999. General physical properties of paper and board. In: Fapet O. (ed). Papermaking Science and Technology. Book 17. Pulp and Paper Testing. Aalto University, Finland, 136-161. https://www. puunjalostusinsinoorit.fi/site/assets/files/4218/vol17 pulp and paper testing toc.pdf

Li H., Cui R., Peng L., Cai Sh., Li P., Lan T., 2018. Preparation of antibacterial cellulose paper using layer-by-layer assembly for cooked beef preservation at ambient temperature. Polymers Journal, 10 (1): 15-30. https://doi.org/10.3390/ polym10010015

Lindqvist R., 2006. Estimation of Staphylococcus aureus growth parameters from turbidity data: Characterization of strain variation and comparison of methods. Applied and Enviromental Microbiology, 72 (7): 4862-4870. https://doi. org/10.1128/aem.00251-06

Ling Y., Luo Y., Luo J., Wang X., Sun R., 2013. Novel antibacterial paper based on quaternized carboxymethyl chitosan/organic montmorillonite/Ag NP nanocomposites. Industrial Crops and Products, 51 (2): 470-479. https://doi. org/10.1016/j.indcrop.2013.09.040

Liu R., Yu H., Huang Y., 2005. Structure and morphology of cellulose. Cellulose, 12 (4): 25-34.

Majidi R., 2016. Electronic properties of graphyne nanotubes filled with small fullerenes: A density functional theory study. Journal of Computational Electronics, 15 (4): 12631268. https://doi.org/10.1007/s10825-016-0925-z

Mauyer H., 1998. Opportunities and challenges for starch in the paper industry. Starch -Starke, 50 (9): 396-402. https:// doi.org/10.1002/(sici)1521-379x(199809)50:9<396::aidstar396>3.0.c0;2-8

Pang X., Yun Z., Chen J., Zheng J. Z., 2015. Study on the antibacterial paper coated by ZnO/MFC for food packaging. Applied Mechanics and Materials, 731: 457-461. https:// doi.org/10.4028/www.scientific.net/amm.731.457

ParkS. I., Zhao Y., 2004. Incorporation of a high concentration of mineral or vitamin into chitosan-based films. Journal of Agricultural and Food Chemistry, 52 (7): 1933-1942. https://doi.org/10.1021/if034612p

Pierce F. T., 1930. The mechanism of growth in the cotton hair. Transactions of the Faraday Society, 26: 809-813.

Pornasir N., Peyghambardoost J., Peyghambardoost H., 2016. The study of physical, mechanical and antibacterial properties of nanobio-composite films based on starch containing silver, oxide and copper oxide nanoparticles. Journal of New Food Technologies, 14 (4): 64-69.

Retulainen E., Nurminen I., 1993. Effects of sodium chlorite delignification and alkaline extraction on bonding of CTMP fibers and the efficiency of dry strength additives. Paperi ja Puu (Paper and Timber), 75 (7): 499-504.

Robinson J. V., 1980. Fiber bonding. In: Casey J. P. (ed). Pulp and Paper: Chemistry and Chemical Technology. John Wiley \& Sons, USA, 915-963.

Samyn P., Deconinck M., Schoukens G., Vanden A. H., 2010. Modifications of paper and paperboard surfaces 
with a nanostructured polymer coating. Progress in Organic Coatings, 69 (4): 442-454. https://doi.org/10.1016/i. porgcoat.2010.08.008

Santos C. M., Mangadlao J., Ahmed F., Leon A., Advincula R. C., 2012. Graphene nanocomposite for biomedical applications: fabrication, antimicrobial and cytotoxic investigations. Nanotechnology, 23 (4): 39-51. https://doi. org/10.1088/0957-4484/23/39/395101

Sondi I., Salopek-Sondi B., 2004. Silver nanoparticles as antimicrobial agent: A case study on $E$. coli and model for Gram-negative bacteria. Journal of Colloid and Interface Science, 275 (1): 177-182. https://doi.org/10.1016/ s0021-9797(04)00163-8

Stratton R. A., 1991. Characterisation of fiber-fiber bond strength from paper mechanical properties. TAPPI International Paper Physics Conference, Kona, Hawaii, Atlanta, 561-577.

Taghiyari H. R., Kalantari A., Kalantri A., Avramidis S., 2019. Effect of wollastonite nanofibers and exposure to Aspergillus niger fungus on air flow rate in paper. Measurement, 136: 307-313. https://doi.org/10.1016/j. measurement.2018.12.109

Tang J., Chen Q., Xu L., Zhang S., Feng L., 2013. Graphene oxide-silver nanocomposite as a highly effective antibacterial agent with species specific mechanisms. ACS Applied Materials and Interfaces, 5: 3867-3874. https:// doi.org/10.1021/am4005495

Tassou C. C., Nychas G. J., 1995. Antimicrobial activity of the essential oil of mastic fun on gram-positive and gram-negative bacteria in broth and model food systems. International Biodeterioration \& Biodegradation Journal, 36 (2): 411-420. https://doi.org/10.1016/0964-8305(95)00103-4

Testova L., 2006. Hemicelluloses extraction from birch wood prior to kraft cooking, Extraction optimization and pulp properties investigation. Master's thesis, Lulea University of Technology, Sweden, 70 p.

Tran P. A., Webster T. J., 2011. Selenium nanoparticles inhibit Staphylococcus aureus growth. International Journal of Nanomedicine, 6: 1553-1558. https://doi.org/10.2147/ ijn.s21729

Tunc S., Angellier H., Cahyana Y., Chalier P., Gontard N., Gastaldi E., 2007. Functional properties of wheat gluten/ montmorillonite nanocomposite films processed by casting. Journal of Membrane Science, 289 (1): 159-168. https:// doi.org/10.1016/i.memsci.2006.11.050

Wang H., Jing Y., 2016. Effects of a Chitosan Coating Layer on the Surface Properties and Barrier Properties of Kraft Paper. BioResources, 11 (1): 1868-1881. https://doi. org/10.15376/biores.11.1.1868-1881

Werner O., Wagberg L., Lindstrom T., 2005. Wetting of structured hydrophobic surfaces by water droplets. Langmuir, 21: 12235-12243. https://doi.org/10.1021/ $\underline{\text { la052415+ }}$

Wu T., Farnood R., 2014. Cellulose fibre networks reinforced with carboxymethyl cellulose/chitosan complex layer-bylayer. Carbohydrate Polymers, 114 (C): 500-505. https:// doi.org/10.1016/i.carbpol.2014.08.053

Xia T., Kovochich M., Nel A. E., 2008. Comparison of the mechanism of toxicity of zinc oxide and cerium oxide nanoparticles based on dissolution and oxidative stress properties. ACS Nano, 2 (10): 2121-2134. https://doi. org/10.1021/nn800511k

Yazdani O., Asadpour Gh., Rasooly E., Imani R., 2014. Effect of cationic polyacrylamide and antibacterial nanosilver on bank-note paper properties. Lignocellulose, 3 (1): 3-14.

Zhou N., Menga N., Ma Y., Liao X., Zhang J., Li L., et al., 2009. Evaluation of antithrombogenic and antibacterial activities of a graphite oxide/heparin-benzalkonium chloride composite. Carbon, 47 (5): 1343-1350. https://doi. org/10.1016/i.carbon.2009.01.025

\begin{tabular}{|c|c|}
\hline \multicolumn{2}{|c|}{ Akhtari et al. - Author's contributions } \\
\hline CONTRIBUTOR ROLE & CONTRIBUTOR NAMES \\
\hline Conceptualization & $\begin{array}{l}\text { Akhtari M., Aliabadi M., } \\
\text { Arefkhani M. }\end{array}$ \\
\hline Data Curation & $\begin{array}{l}\text { Akhtari M., } \\
\text { Dehghani- Firouzabadi M. }\end{array}$ \\
\hline Formal Analysis & Akhtari M., Arefkhani M. \\
\hline Funding Acquisition & $\begin{array}{l}\text { Islamic Azad University- } \\
\text { Bojnourd Branch, in charge } \\
\text { of the research: Akhtari M. }\end{array}$ \\
\hline Investigation & $\begin{array}{l}\text { Akhtari M., Aliabadi M., } \\
\text { Arefkhani M. }\end{array}$ \\
\hline Methodology & $\begin{array}{l}\text { Akhtari M., } \\
\text { Dehghani- Firouzabadi M. }\end{array}$ \\
\hline Project Administration & $\begin{array}{l}\text { Akhtari M., } \\
\text { Dehghani- Firouzabadi M. }\end{array}$ \\
\hline Resources & $\begin{array}{l}\text { Akhtari M., } \\
\text { Dehghani- Firouzabadi M., } \\
\text { Aliabadi M., Arefkhani M. }\end{array}$ \\
\hline Software & Arefkhani M. \\
\hline Supervision & $\begin{array}{l}\text { Akhtari M., } \\
\text { Dehghani- Firouzabadi M. }\end{array}$ \\
\hline Validation & $\begin{array}{l}\text { Akhtari M., } \\
\text { Dehghani- Firouzabadi M., } \\
\text { Aliabadi M., Arefkhani M. }\end{array}$ \\
\hline Visualization & Akhtari M., Arefkhani M. \\
\hline $\begin{array}{l}\text { Writing - Original Draft } \\
\text { Preparation }\end{array}$ & Akhtari M. \\
\hline $\begin{array}{l}\text { Writing - Review } \\
\text { \& Editing }\end{array}$ & Akhtari M. \\
\hline
\end{tabular}

Bois et Forêts des Tropiques - Revue scientifique du Cirad

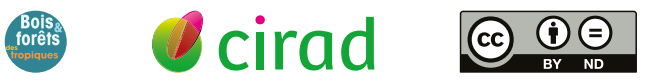

Cirad - Campus international de Baillarguet, 34398 Montpellier Cedex 5, France - Contact : bft@cirad.fr - ISSN : L-0006-579X 